\title{
Tradisi Yang Berkembang Di Seputar Situs Candi Petirtaan Cabean
}

Kunti

\section{Hari Lelono}

Keywords: ethnography, ethnoarchaeology, tradition, culture, classic, hindu-buddha

\section{How to Cite:}

Lelono, H. (2003). Tradisi Yang Berkembang Di Seputar Situs Candi Petirtaan Cabean Kunti. Berkala Arkeologi, 23(1), 109-120. https://doi.org/10.30883/jba.v23i1.866

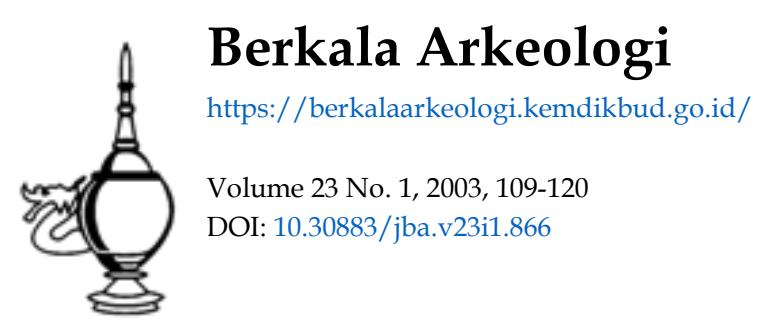

\section{(c) (i) (2)}

This work is licensed under a Creative Commons Attribution-NonCommercial-ShareAlike 4.0 International License. 


\title{
TRADISI YANG BERKEMBANG \\ DI SEPUTAR SITUS CANDI PETIRTAAN CABEAN KUNTI
}

\author{
TM Hari lelono
}

\begin{abstract}
ir sebagai Sumber Kehidupan
A Di dalam masyarakat kuna peranan air terutama air suci (sakral) yang disebut 1 tirta sangat penting. Dalam lambang-lambang kuna, terdapat anggapan bahwa segala sesuatu yang ada di bumi ini berasal dari air. Dalam naskah kuna India Phavieyottara purana dikatakan bahwa "water you are of the source of everything and every existence". Dengan demikian air dianggap sebagai sumber segala kehidupan serta sebagai zat yang sangat penting bagi kehidupan. Air merupakan zat yang karena kekuatan yang dikadungnya dianggap dapat menghapuskan dosa, menyucikan serta melahirkan kehidupan kembali. Oleh karenanya air selalu akan dipakai di dalam setiap upacara kelahiran serta kematian (Soeroso, 1982).
\end{abstract}

Sejalan dengan pernyataan Soeroso, Stutterheim (1937), mengkaji air secara lebih spesifik yaitu yang khusus bertalian dengan peranan air di Candi Jolotundo, Jawa Timur, dapatlah diketahui bahwa air suci itu mempunyai daya gaib yang sangat istimewa, ialah sebagai "penghidup" atau sebagai "pembangkit tenaga hidup". Air digunakan sebagai pembasuh arca tadi adalah air suci, air yang jatuh ke dalam yoni, melalui cerat yoni tersebut air mengalir (Soekmono, 1977).

Dalam bahasa Jawa kuna kata tirtha berarti air suci. Kata matirtha berair sedangkan kata-kata tirthasemana dan tirthayatra berarti berziarah atau pergi ke tempat-tempat pemandian suci (Woyowasito.S, 1977). Di Jawa tempat tempat suci (Candi) yang berkaitan dengan air/ petirtaan tersebar di Jawa Timur (Simbatan, Tikus, Penataran, Jolotundo, dll) Jawa Tengah (Candi Umbul, Gringsing, Bale Kambang, Ratu Boko, dil), di Bali juga banyak dapat kita jumpai seperti Tirta Empul, Yeh Pulu, Goa Gajah, dan Gunung Kawi. Tradisi masa Hindhu/ Budha tersebut terus berlanjut sampai pada masa Islam di Jawa, berupa tradisi siraman, padusan dan mandi kembang, bertempat pada sendang atau umbul yang secara tradisional telah ada sejak masa klasik (Hindu/ Budha) dan dianggap keramat. Upacara tersebut dilakukan biasanya pada saat menjelang Hari Raya Fitri atau menjelang hari puasa, serta seseorang mempunyai hajad dalam upacara ritual "proses kehidupan"/ life circles seperti misalnya upacara mitoni (tujuh bulan kehamilan), serta untuk mengobati orang sakit dengan cara diminum atau dimandikan yang terlebih dahulu diberi mantera oleb seorang dukun. Sedangkan tradisi padusan dimaksudkan untuk membersihkan diri jiwa dan raga dengan cara mandi pada kolam-kolam yang dianggap keramat/ suci. Mandi dengan membersihkan diri tersebut mengandung makna simbolis. Manusia harus bersih secara rohaniah dan jasmaniah, dengan maksud yang melambangkan, manusia itu kembali 
kepada keadaan semula bersih dan suci bebas dari segala kesalahan, kemudian setelah mandi dianggap sebagai manusia baru.

Tradisi yang lebih bernuansa masa yang lebih kuna berkaitan dengan unsur-unsur budaya/ agama Hindu-Budha masih dapat kita temukan di Candi petirtaan Cabean Kunti daerah Cepogo, Boyolali, Jawa Tengah. Dalam tradisi tersebut ada yang dilakukan secara massal disebut nguras lepen dan secara perorangan/ individu dikenal dengan ngirim lepen. Tradisi ngirim lepen merupakan bagian utama dalam proses kehidupan manusia sejak dia lahir, anak-anak, dewasa, kawin dan mati. Kedua tradisi tersebut sama-sama menggunakan air yang ada/ diambil di sendang (situs) sebagai materi utama.

Tradisi yang masih dilakukan secara turun-temurun tersebut merupakan bagian dari sistem nilai-nilai kehidupan masyarakat setempat, sebagai sesuatu yang seharusnya terus dilestarikan sebagai penghayatan dan penghormatan terhadap leluhur. Hal tersebut dikatakan oleh Koentjaraningrat, bahwa Sistem nilai budaya secara tidak langsung menjadi salah satu pedoman hidup yang mereka hormati. Karena sisten nilai budaya tersebut menjadi salah satu pedoman hidup bagi kelakukan manusia, nilai budaya tersebut tidak mudah hilang meskipun mengalami transformasi dari masa ke masa. Dengan perkataan lain transformasi budaya yang terjadi, biasanya tidak akan mampu menggeser substansi nilai-nilai di dalamnya (Koentjoroningrat, 1974). Tradisi berupa pemanfaatan air untuk kegiatan ritual yang masih dapat kita jumpai pada beberapa kelompok masyarakat Jawa, dalam kurun waktu tertentu pasti akan mengalami penurunan baik secara kuantitas dan kualitanya. Hal tersebut perlu kita tanggapi untuk segera merekam semua kegiatan ritual sebagai data etnografis, yang dapat digunakan untuk penjelasan konsep-konsep air pada masyarakat Jawa kuna dan masa kini

Masyarakat Cabean Kunti adalah masyarakat yang mayoritas masih berpola pikir sederhana dalam menanggapi tantangan hidup. Dalam masyarakat tardisional, pola berpikir tidak dapat dipisahkan dari pengaruh lingkungan alam sekitarnya. Irama alam merupakan irama hidup masyarakat pula. Mereka terikat secara akrab dengan alam semesta dan kekuatan-kekuatannya. Orang selalu berpartisipasi dengan irama alam dan secara mental mereka tidak terlepas dari kekuatannya (Moetjipto, 1973). Dalam konteks tersebut, masyarakat akan melakukan hal-hal yang pernah dilakukan oleh pendahulunya biasanya berupa tradisi/ adat berkaitan dengan keselarasan kehidupan manusia sehari-hari. Secara sadar mereka melakukan tradisi tersebut dengan suatu harapan dalam kehidupannya akan memperoleh kedamaian dan kesempurnaan hidup.

Dunia tempat berkembangnya manusia adalah dunia yang hidup dan selalu mengalami perubahan. Demikianpula masyarakat dan kebudayaan manusia dimanapun berada selalu dalam keadaan berubah. Hal ini disebabkan adanya keinginan manusia untuk 
terus mengembangkan kemampuannya, agar dengan mudah menjalani kehidupan yang disesuaikan dengan perkembangan jaman. Pada era globalisasi ini, manusia tidak pernah cepat merasa puas akan yang dikerjakannya, sehingga selalu berupaya inovatif untuk menemukan menemukan hal-hal baru. Hal yang baru itu bisa berasal dari penambahan yang pernah ada, pengurangan yang pernah ada, penerimaan dari luar atau mencipta dari tidak ada menjadi ada. Tentu saja hal tersebut menyebabkan terjadinya perubahan dalam bidang kehidupan. Khususnya dalam hal ini perubahan kebudayaan. Menurut Parsudi Suparlan (1987), perubahan kebudayaan adalah perubahan yang terjadi dalam sistem ide yang dimiliki bersama oleh sejumlah warga masyarakat, misalnya aturan-aturan, nilai-nilai, norma, adat-istiadat, rasa keindahan, bahasa termasuk di sini juga upacara tradisional.

Bertolah dari pemikiran-pemikiran di depan, pada masyarakat Cabean Kunti telah terjadi perubahan/transformasi budaya. Perubahan yang terjadi hanya pada kulitnya saja yakni tata cara dan perlengkapan sesaji, bahasa, dan pakaian yang digunakan, sedangkan unsur religi yakni 'penghormatan' terhadap air/ tirta/ banyu panguripan merupakan substansi yang sampai kini masih dipertahankan oleh masyarakat setempat.

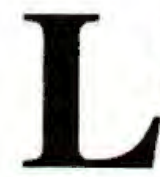

\section{ingkungan Situs Candi Petirtaan Cabean Kunti}

Dalam agama Hindu dan Budha yang berasal dari India, terdapat konsep tentang penempatan bangunan suci pada suatu lokasi. Konsep itu adalah bahwa tempat-tempat suci berada di gunung atau tempat-tempat yang tinggi (ksetra) dan tempat yang dekat dengan air (tirtha). Situs Cabean Kunti merupakan bangunan petirtaan, terletak di lereng pegunungan dan berada dekat sumber air yang dialiri oleh dua buah sungai kecil Cabean dan Kunti, dengan demikian bangunan-bangunan tersebut mengikuti konsep ksetra dan tirtha.

Lingkungan situs Cabean Kunti sangat teduh oleh rimbunan tajuk dari pohon-pohon sekitarnya. Beberapa jenis tumbuhan yang penting antara lain: lansep (Lansium domesticum), nangka (Artocarpus heterophyllus), bibis, randu alas (Ceiba pentandra), duwet (Eugenia cumini), bendo, lerak (Sapindus rera), kemuning, wiyu, aren (Arenga pinata), preh (Ficus sp), kelapa (Cocos nucifera), suren, doyo, bulu, wuni (Antidesma bunius), mojo (Feronia limonia), pule, dan pohon penjirit. Pada umumnya pohonpohon besar (bibis, lerak, wiyu, dan pohon pule) tersebut berada sekitar situs berfungsi sebagai pelindung sumber-sumber air/mata air yang ada di situs.

Situs Cabean Kunti merupakan suatu kompleks bangunan masa klasik yang letaknya berjajar mengikuti alur sebuah sungai kecil. Di sepanjang sungai tersebut dahulu terdapat tujuh bangunan, yang masing-masing berfungsi untuk menampung air dari mata air. Dari ketujuh bekas bangunan penampungan air tersebut hanya 3 bangunan 
yang masih tampak agak utuh (Sendang Lereban, Sendang Keputren, Sendang Kesucian), dua buah masih tampak bentuknya dengan sisa-sisa batunya (Sendang Pertapan, Sendang Penguripan), dan dua buah sudah tidak diketahui bentuknya karena batu-batunya sudah hilang (Sendang Jangkang, Sendang Lanangan).

Salah satu bangunan yang masih tampak utuh, pada dinding pagarnya tampak ada pahatan beberapa relief yang menggambarkan sekelompok orang (kelompok laki-laki dan perempuan) yang dipisahkan sedang menghadapi sebakul nasi lengkap dengan lauk-pauknya. Terdapat pula relief-relief yang menggambarkan adegan fauna burungburung, seperti merak (Pavo munticus), bangau (Concinidae), gagak dan betet. Selain itu ditemukan pulah pahatan katak (Rana sp.) dan ikan (Pisces). Burung bangau membawa katak, merak digambarkan sedang membawa bulir padi dengan paruhnya. Kemungkinan binatang dan biji-bijian yang dibawa burung-burung di paruhnya, adalah jenis makanannya. Relief-relief tersebut selain berfungsi sebagai hiasan dari suatu arsitektur bangunan diduga mengandung nilai simbolis atau suatu pesan (massege) tertentu dari sistem kepercayaan masa lalu. Simbol-simbol burung (termasuk simbol dengan unsur sayap) biasa dipahatkan pada bangunan petirtaan. Dalam prasasti Çiwagrêha disebutkan adanya doa kepada tiga kelompok burung yaitu bangau, gagak, dan angsa, dan kepada para pedagang. Menurut Casparis mereka diperintahkan mandi di petirtaan (tîrtha) untuk mendapatkan berkah dalam perjalanan sehingga kembali dengan selamat (siddhayâtra) (Casparis, 1956). Penggambaran relief-relief burung dan orang-orang yang menghadap sebakul nasi dengan laukpauknya di situs Cabean Kunti kemungkinan juga menggambarkan kegiatan ziarah ke petirtaan (tîrtha) untuk mendapatkan siddhayâtra, sebagaimana digambarkan pada prasasti Çiwagrêha. Menurut Soeroso relief burung-burung yang dipahatkan di situs Cabean Kunti tersebut kemungkinan merupakan tokoh-tokoh dalam ceritera tantri. Mengingat petirtaan itu merupakan petirtaan suci, maka pemahatan relief cerita itu dilakukan dengan tujuan untuk mengajarkan masalah-masalah yang berhubungan dengan moral. Dengan berziarah ke petirtaan itu dan melihat relief yang dipahatkan seseorang akan menyadari perbuatannya yang keliru dan kembali ke jalan yang benar (Soeroso, 1982).

Bentuk bangunan di situs Cabean Kunti, pada umumnya berdenah empat persegi panjang dengan bahan batu andesit. Pada bagian depan terbuka (tanpa dinding) dengan batu-batu datar sejajar tanah, sedangkan di samping kiri-kanan dan belakang terdapat dinding batu. Pada bagian sisi dalam tembok terdapat gambar-gambar relief. Biasanya situs petirtaan dalam keletakannya pada tata ruang makro selalu mempunyai konteks dengan situs lain, terutama berkaitan dengan pertapaan atau candi. Keterkaitan suatu petirtaan dengan situs lain secara konseptual dapat dipahami sebagai sarana laku spiritual untuk mencapai prinsip tertinggi (Nareswara, 1993). Bangunan Petirtaan merupakan salah satu bentuk bangunan suci dan dianggap sangat penting, karena dapat mengeluarkan dan menampung air yang dianggap sebagai tirta. Dalam 
aktifitas masyarakat yang menggunakan tirta atau air suci mengandung dua pengertian, yaitu menyatukan kekuatan serta menciptakan kehidupan kembali. Dengan menggunakan tirta pada upacara-upacara religius, mereka seolah-olah dapat mengembalikan kehidupan yang selaras dengan alam serta akan terciptanya cita-cita yang mereka harapkan (Soeroso, 1982). Demikian pula petirtaan Cabean Kunti yang berjumlah tujuh bukan merupakan hal yang kebetulan saja, melainkan memang dibuat dengan acuan konsep-konsep kepercayaan/ agama Hindu/ Budha. Dalam kaitannya dengan tirta, maka nilai tujuh tersebut dapat dihubungkan dengan tujuh sungai suci (Sapta Ganggã) yang sangat dihormati baik di India maupun di Bali. Sehingga dapat disimpulkan bahwa fungsi petirtaan Cabean Kunti adalah sebagai bangunan suci (Soeroso, 1982).

Situs Cabean Kunti terletak di Dusun Kunti dan Dusun Balong Margomulyo, Desa Cabean Kunti, Kecamatan Cepogo. Situs terdiri dari 7 buah bangunan pemandian yang terbuat dari batu andesit yang tersebar di sepanjang tepi sungai kecil (jurang) yang mengalir ke arah timur laut. Lokasi ini berada pada kordinat $07^{\circ} 30^{\prime} 13,8^{\prime \prime}$ LS dan $110^{\circ} 32^{\prime} 15,7^{\prime \prime}$ BT. Sedangkan candi 7 terletak di Dukuh Balong, Desa Cabean Kunti, Kecamatan Cepogo, Kabupaten Boyolali. Lokasi ini berada pada koordinat $07^{\circ}$ $30^{\prime} 13,7^{\prime \prime}$ LS dan $110^{\circ} 32^{\prime} 20$, 2" BT. Penduduk setempat menamakan masing-masing candi tersebut dengan nama-nama yang diketahuinya sudah sejak jaman kakek-nenek mereka, sebagai berikut:

1. Sendang Jangkang untuk candi 1, terletak paling barat, batu-batu candinya sudah hilang terbawa banjir. Saat ini tinggal dua buah batu saja yang terletak di tepi sendang. Kondisi sendang saat ini sudah diberi tanggul dari batu dan disemen. Aimya dimanfaatkan untuk air minum oleh masyarakat sekitar yang disalurkan ke rumahrumah penduduk melalui pipa pralon.

2. Sendang Pertapan untuk candi 2, terletak di sebelah timur candi 1 berjarak $\pm 75 \mathrm{~m}$. Candi ini masih agak utuh berbentuk empat persegi panjang dengan ukuran $150 \times 470$ $\mathrm{cm}$, tinggi pagar $30 \mathrm{~cm}$. Dinding pagarnya sudah tidak ada, tetapi masih menyisakan dua buah fragmen kemuncak pagar dan dua buah fragmen antefiks. Arah hadap ke sungai yaitu E $120 \mathrm{~S}$.

3. Sendang Lereban untuk candi 3, terletak di sebelah timur candi 2 berjarak $\pm 10 \mathrm{~m}$. Candi ini juga masih agak utuh, bahkan dinding-dinding pagarnya masih berdiri. Candi ini juga berbentuk empat persegi panjang dengan ukuran $468 \times 165 \mathrm{~cm}$, tinggi pagar $95 \mathrm{~cm}$. Di atas sudut-sudut dinding pagar terdapat kemuncak pagar, tetapi tinggal tiga buah saja. Di kedua ujung pagar terdapat relief gana-gana. Pada dinding pagar bagian dalam terdapat relief-relief antara lain pada dinding selatan terdapat 3 ekor burung betet masing-masing mematuk seuntai padi, dan 2 ekor kuntul, yang di depan mematuk ikan yang di belakang mematuk katak. Pada dinding barat terdapat 
relief 2 orang jongkok dan 3 orang menghadap sebakul nasi yang di atasnya terdapat lauk-pauk berupa ikan, relief-relief tersebut terdapat pada dinding barat sebelah selatan dan utara. Relief bagian selatan semuanya wanita dan menghadap ke utara, sedangkan relief bagian utara semuanya laki-laki dan menghadap ke selatan. Sedangkan pada dinding pagar sebelah utara terdapat relief 2 ekor merak masingmasing mematuk setangkai buah-buahan dan 3 ekor burung bangau masing-masing mematuk burung kecil. Pada dinding pagar bagian luar terdapat relief-relief dekoratif berupa ceplok bunga.

4. Sendang Lanangan untuk candi 4 , terletak di sebelah timur candi 3 berjarak \pm 60 $\mathrm{m}$. Batu-batu candinya sebagian besar sudah hilang, tinggal dua buah batu candi saja satu di antaranya berupa pelipit sisi genta. Ukuran bangunan 230 X $400 \mathrm{~cm}$.

5. Sendang Penguripan untuk candi 5, terletak di sebelah utara candi 4 berjarak \pm 10 $\mathrm{m}$. Candi ini berukuran lebih kecil berbentuk bujursangkar. Tidak terdapat relief. Airnya tampak lebih jernih dari candi-candi yang lain. Ukuran $97 \times 127 \mathrm{~cm}$.

6. Sendang Keputren untuk candi 6, terletak di sebelah timur candi 5 berjarak $\pm 10 \mathrm{~m}$. Candi ini tampak masih agak utuh, berbentuk empat persegi panjang. Namun pada dinding-dinding pagar tidak terdapat relief. Ukuran $155 \times 468 \mathrm{~cm}$, tinggi $130 \mathrm{~cm}$.

7. Sendang Kesucian untuk candi 7. terletak cukup jauh di sebelah timur candi 6 berjarak $\pm 50 \mathrm{~m}$. Candi ini tampak paling utuh dibandingkan dengan 6 candi sebelumnya. Candi ini berbentuk empat persegi panjang. Ukuran $174 \times 518 \mathrm{~cm}$, tinggi $55 \mathrm{~cm}$. Pada dinding-dinding pagarnya juga tidak tampak adanya relief-relief binatang/ manusia, kecuali beberapa relief hiasan dekoratif.

\section{$\mathbf{T}$}

\section{radisi yang Hidup Sekitar Situs}

Masyarakat Cabean Kunti masih menghormati keberadaan situs tersebut dengan beberapa bukti yaitu masih terdapatnya bekas aktivitas ritual seperti sesajian pada tempat-tempat tertentu yang dianggap keramat. Keberadaan sesaji berkaitan erat dengan tradisi adat masyarakat berkaitan dengan kehidupan sehari-hari masyarakat, seperti peristiwa perkawinan, kehamilan, dan peristiwa tertentu yang dianggap penting. Kelompok iindividu atau masyarakat tersebut selalu ngirim sesaji ke sendang dengan suatu maksud tertentu. Tradisi yang masih ada dan dilakukan secara massa oleh penduduk desa sampai saat ini adalah Nguras lepen.

Dari pengamatan dan wawancara, sekurangnya dapat diperoleh pemahaman, bahwa: terdapat dua hal yang penting dalam aktivitas masyarakat, pertama yakni tradisi berkaitan dengan life circles/ peristiwa hamil tujuh bulan dan perkawinan, selain itu pada beberapa individu jika mempunyai suatu keinginan tertentu ada yang ngirim ke 
lepen dengan maksud keinginannya akan terkabul. Tradisi yang sangat penting dan melibatkan orang banyak adalah tradisi Memetri lepen atau nguras sendang ${ }^{\dagger}$. Tradisi ini dilakukan secara bergotong royong oleh masyarakat pengguna air dari Cabean Kunti. Tradisi ini tidak ada yang mengetahui dilakukan sejak kapan, namun menurut keterangan penduduk hal tersebut sudah dilakukan oleh para nenek moyang mereka, dan tidak ada seorangpun yang berani melanggar ketentuan. Secara naluriah tradisi tersebut masih hidup dengan baik, sedangkan keuntungan yang diperoleh warga masyarakat adalah air sendang menjadi bersih kembali, membawa berkah, keselamatan dan rasa bersyukur yang sangat mendalam kepada Maha Pencipta.

Upacara pembersihan sendang dilakukan selapan (35 hari) sekali dalam hitungan Jawa, yang jatuh setiap bulan sekali pada hari Selasa Kliwon, Pada pagi hari sekitar pukul 06.00 - 07.00 dilakukan pembersihan seluruh sendang yang ilakukan oleh sepuluh dusun pengguna air yang terdapat di sekitar situs Cabean Kunti. Setelah pembersihan sendang, kira-kira sehabis luhur pukul 13.00 diadakan wilujengan di rumah pak RT setempat . Upacara ini dilakukan oleh sepuluh Dusun pengguna air sendang tersebut. Kesepuluh Dusun itu adalah: Sidotopo, Lerep, Cabean, Kunti, gargosari, Ngajian, Balong, Kedungbanteng, Sidorejo dan Watu Anten. Tradisi ini sudah dilakukan oleh generasi sebelum mereka/ secara turun temurun dengan cara mengirim ke sungai berupa sesaji. Disebut dengan istilah wilujengan dengan mengirim ambengan berupa: Nasi, mentho, ulam ayaam, jangan-janganan dan goreng-gorengan.

Menurut informasi penduduk dan juru kunci sendang (Pak Maksan) mengenai namanama ada kaitannya dengan peristiwa dan gejala alam tertentu, seperti misalnya: (1) Sendang Jangkang, (2) Sendang Pertapan/ Sidotopo, (3) Sendang Lereban, (4) Sendang Lanangan, (5) Sendang/ Sumur Panguripan, (6) Sendang Keputren, dan (7) Sendang Kesucian/ Semboja.

Doa untuk mengiringi wilujengan tersebut menggunakan doa pembukaan bahasa Arab yang diselengi dengan permohonan menggunakan bahasa Jawa. Salah satu doa ditujukan kepada Nabi Muhammad, Nabi Iliyas sebagai penguasa jagad/ bumi dan Nabi Qidhir sebagai penguasa air, kemudian kepada seluruh Dahyang yang ada di sungai terebut. Tujuan dari doa adalah untuk beterimakasih dan mohon air yang melimpah, karena sudah memberikan berkah berupa air sebagai pemenuhan kebutuhan masyarakat.

Pengertian Nguras Sendang. membersihkan secara fisik yang dismbolkan pada pembersihan jiwa dan pikiran manusia untuk selalu bersih dan suci. 


\section{$\mathbf{P}$}

eralatan dan perlengkapan upacara:

Perlengkapan dan peralatan upacara merupakan hal yang sangat penting dalam tardisi masyarakat desa pengguna air. Hal tersebut akan dapat mempengaruhi suasana yang lebih magis, doa-doa yang diucapakan sebagai berikut:

- Doa untuk perorangan, para punden nyuwun berkah ngangge toya, supados diberkahi, kali jogo, baurekso, ageng-alit, rakyat diparingi seger lan selamet. Sesajian diletakkan dalam tempat (takir) dari daun pisang sebagai alas, kendi dan empluk, kendi wadah air putih ditutupi dengan daun atau kertas ujungnya, empluk berisikan beras kuning, uang, telor ayam.

- Doa secara massal: pembacaan wasillah, kemudian ditujukan kepada Nabi Muhammad, Nabi Illyas (penguasa bumi dan tanah), dan Nabi Qidir (penguasa air), dan kepada seluruh penguasa dahyang/ baurekso wit-witan, lepen, sobo, omah, nopo duwekel Nabi Sulaiman, sedulur papat lima pancer )(abang, ireng, putih, kuning dan ijo, utara-selatan, barat-timur. kemudian dibacakan solawat nabi, dan terakhir doa tolak-balak. Perlengkapan sesaji pada peristiwa itu adalah: Tukon pasar terdiri dari: pisang, telo, gralen/tales, uwi, gembili, kacang, jambu, semongko, dan lain-lain. Bunga terdiri dari mawar merah $($ abang $)=$ sedulur papat lima pancer. Mawar putih $($ putih $)=$ simbol darah putih/ zat hidup, Kembang kantil/ kenongo (kuning/ireng)= sebagai sumber tenaga, kekuatan/ bayu. Nasi tumpeng, ayam ingkung, uang, rokok, kinang dan menyan.

Pakaian yang digunakan dalam upacara yang dilakukan oleh individu maupun kelompok menggunakan pakain bebas asalkan sopan dan rapi. Pelaksanaan untuk individu yang misalnya harus mandi pada ketujuh sendang, biasanya dilakukan pada malam hari, dengan cara mandi atau mencelupkan badannya dalam sendang, atau cukup disiram dengan air sendang.

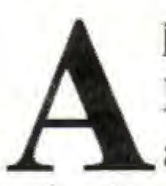

\section{ktivitas Sakral/ Ritual}

Manusia dalam usaha memenuhi kebutuhan hidup yang bersifat imanen, pasti akan melakukan suatu kegiatan yang berkaitan dengan ha-hal yang bersifat sakral/ suci. Hal tersebut diperlukan untuk menghubungkan dan membersihkan batin dari segala macam kotoran. Wujud dari penghubung dua dunia tersebut (makrokosmos dan mikrokosmos) biasanya berupa upacara. Upacara sakral biasanya dilengkapi dengan serangkaian aturan/ tata cara untuk melaksankan kegiatan tersebut yang dikenal dengan ritus. Bagi masyarakat Cabean Kunti, hal berkaitan dengan aktivitas sakral/ ritual tersebut dilakukan oleh kelompok secara massal dan ada juga yang dilakukan oleh perorangan/ individu. Upacara sakral yang dilakukan secara massal dinamakan nguras lepen, secara lahiriah bermakna membersihkan dari segala 
kotoran yang jatuh ke dalam sendang, sedangkan yang imanen yakni menyucikan lagi lokasi dan segala yang ada di tempat itu supaya layak dan memberikan manfaat bagi fisik dan batin setiap warga desa.

Kegiatan ritual yang penting dilakukan yang masih berlangsung sampai saat ini adalah secara massal. Sebelum atau sesudah melakukan pembersihan sendang terlebih dahulu dilakukan upacara menurut Agama Islam yang dilakukan di Masjid atau di rumah ketua RT setempat dengan iringan doa-doa yang semuanya ditujukan kepada para penguasa alam, air, tumbuhan yang ada disekitarnya. Upacara yang dipimpin oleh ketua RT tersebut terdapat dua versi mengenai waktu penyelenggaraannya. Versi pertama yang dilakukan oleh penduduk Dusun Cabean dan Kunti Doa-doa dan sesaji (nasi golong) dilakukan setelah selesai membersihkan sendang, sekitar pukul 12.00 WIB. Versi kedua, dilakukan oleh penduduk Dusun Balongan doa dilakukan pada malam hari atau malam Selasa Kliwon, kemudian sesudah subuh mereka bersamasama membersihkan sendang Semboja dan Kali Semboja. Dua versi waktu penyelenggaraan doa tersebut, tidak menjadi masalah bagi penduduk masing-masing dusun tersebut, yang penting waktu melakukan pembersihan dilakukan secara bersama-sama sesudah subuh oleh seluruh penduduk Desa Cabean Kunti;

\section{RANSFORMASI BUDAYA DI SITUS CABEAN KUNTI}

Sebelum masuknya agama Hindu-Budha di Jawa, masyarakat sudah mengenal agama asli yang terdapat unsur-unsur dari tradisi prasejarah, yakni pemujaan terhadap benda-benda (pohon, batu, sungai, dan lain-lain) yang dipandang aneh/ mempunyai kekuatan magis. Kepercayaan dengan adat-istiadat yang melengkapinya kemudian berkembang lagi dengan masuknya agama dan budaya yang sangat kuat mempengaruhi aspek-aspek kehidupan masyarakat Jawa. Dua unsur budaya prasejarah dan Hindu-Budha dipadukan menjadi satu yang baru, tradisi dan agama ini kemudian berubah lagi dengan masuknya agama Islam ke Jawa, sehingga masyarakat tersebut beralih pada agama baru yakni Islam. Dalam agama yang terkhir tersebut unsur-unsur lama masih sering kita jumpai, utamanya berkaitan dengan hal-hal yang bersifat tradisi atau adat istiadat. Proses munculnya budaya baru tersebut juga terjadi pada masyarakat Desa Cabean Kunti, dalam aktivitas masyarakat masih terdapat unsur-unsur lama yang masih dipertahankan, utamanya hal-hal yang bersifat imanen, seperti adanya upacara membersihkan sendang/ nguras lepen yang dilakukan secara massal, dan ada tradisi yang dilakukan oleh perorangan/ individu, semuanya berfokus pada masalah air/ tritha yang dipandang telah memberikan berkah bagi kehidupan masyarakatnya. Unsur-unsur yang ada pada tradisi masyarakat tersebut adalah sebagai berikut: 
Unsur-Unsur Prasejarah; masih terlihat dari unsur doa-doa ${ }^{\ddagger}$ yang diucapkan seperti menyebut nama baurekso/ dahyang yang bermukim pada alam dan lingkungan masyarakatnya seperti, sungai, air, rumah, pohon dan penjuru mata angin. Religi masa prasejarah menganggap bahwa pohon, batu besar dan gejala alam lain merupakan kekuatan yang harus dihormati dan sebagai bersemayamnya roh-roh nenek moyang.

Unsur-unsur masa klasik; terdapat dalam legenda Dewi Kunti yang berkronologi masa Hindu, selain itu juga nama/ istilah yang diberikan pada kolam/ sendangsendang yang ada. Meskipun menggunakan bahasa Jawa seperti nama panguripan jika dikaitkan dengan tirtha dalam budaya Hindu masih mengandung unsur masa klasik yang kuat. Unsur-unsur masa klasik dalam doa yang diucapkan, tujuan utama dari upacara itu adalah penghormatan yang tinggi pada Tuhan Yang Maha Esa, atas air yang diberikan pada penduduk desa. Air dalam agama Hindu-Budha seringpula disebut dengan tirtha yang dapat membawa batin manusia menjadi bersih dari noda. Oleh karena itu dapat diinterprestasikan bahwa unsur air/tirta merupakan tujuan utama dari penyelenggaraan upacara tersebut. Selain unsur air/tirta, situs itu sendiri merupakan bangunan/ candi petirtaan, Jadi antara bangunan candi dengan doa dalam upacara terdapat persamaan persepsi dengan latar konsep-konsep agama Hindu.

Unsur Agama Islam; Hal ini tercermin dalam bunyi doa-doa yang diucapkan terlebih dahulu menggunakan pembuka bahasa arab, kemudian menyebut nama-nama nabi; seperti Nabi Muhammad, Illyas dan Qidir, lalu pada bagian penutup menggunakan doa dan bahasa arab. Unsur lain yang dapat kita lihat adalah pakaian yang dikenakan ada yang memakai peci dan sarung.

Terdapat paling tidak tiga unsur kepercayaan/ agama tersebut di depan yang proses terjadinya melalui pentahapan-tahapan dan memakan waktu yang sangat lama. Seperti kita ketahui bahwa kebudayaan Hindu-Budha di Jawa tengah berkembang sejak kurang lebih abad VIII - XII Masehi. Pada masa berikutnya kebudayaan Islam mulai masuk pada kurang lebih abad XVI Masehi di daerah pantai utara (Demak) yang kemudian masuk ke selatan di pedalaman Jawa Tengah dan berkembang sampai saat ini. Faktor-faktor itu menyebabkan perubahan sosial yang besar bagi masyarakat desa setempat untuk menyesuaikan segala adat-istiadat dan upacara tradisonal yang ada. Proses demikian boleh dikatakan telah terjadi transformasi budaya/ sosial.

Pengertian transformasi sosial dalam Ensiklopedi Nasional Indonesia (1991) adalah proses alih bentuk, perubahan menyeluruh dalam bentuk, rupa, sifat watak dan sebagainya, dalam hubungan timbal-balik antara manusia baik sebagai individu maupun kelompok. Faktor-faktor penting yang mungkin terlibat dalam perubahan sosial adalah faktor penduduk, teknologi, nilai-nilai kebudayaan, dan gerakan sosial.

₹ Periksa tentang bunyi doa/mantera yang diucapkan 
Beberapa hal yang menyebabkan timbulnya perubahan sosial adalah timbunan kebudayaan, kontak dengan kebudayaan lain, penduduk yang heterogen, kekacauan sosial dan perubahan itu sendiri. Berkaitan dengan timbunan kebudayaan yang terjadi di situs terdapat tiga unsur budaya, seperti agama asli, agama Hindu-Budha dan terakhir agama Islam. Tiga unsur tersebut dalam prosesnya saling pengaruh mempengaruhi sering disebut dengan akulturasi sehingga muncul suatu bentuk baru, sebagai landasan perilaku masyarakat sehari-hari, begitupula halnya dengan adat tradisi dalam upacara tradisional yang disebut dengan tradisi Nguras Lepen.

\section{$\mathbf{P}$}

\section{enutup}

Daerah lereng gunung Merapi dan Merbabu, rupa-rupanya merupakan tempat Gang sejak jaman dahulu selalu ramai. Di daerab Boyolali pada lereng timur Kunti/ Sumur pitu. Tradisi yang masih hidup adalan tradisi Nguras Lepen yang dilakukan secara massal oleh seluruh warga Desa Cabean Kunti, dan tradisi Ngirim Lepen yang dilakukan oleh perorangan. Dua tradisi yang masih hidup sama-sama ditujukan kepada penguasa alam raya/ Tuhan Yang Maha Esa atas rahmat yang diberikan berupa air yang memberikan kehidupan bagi seluruh warga desa.

Gambaran tradisi yang berkaitan dengan tirtha/ air tersebut, tersebut tercermin dalam aktivitas dan perilaku masyarakat Cebean Kunti sehari-hari (life cultural). Mereka masih percaya hal-hal yang berbau gaib/ angker dan tidak berani dengan sengaja melakukan pelanggaran yang dapat merugikan diri sendiri.

Beberapa catatan berkaitan erat antara budaya materi (arkeologis) dan budaya yang hidup dalam perilaku dan keyakinan masyarakat setempat (etnografis) dapat ringkas sebagai berikut:

- Tradisi penghormatan terhadap air tentunya pernah dilakukan pula pada situssitus candi petirtaan di daerah selain kedua situs Sumur Songo dan Sumur Pitu.

- Telah terjadi transformasi budaya yang berawal dari kebudayaan Hindu/ Budha ke kebudayaan islam dalam tata cara ritual, tetapi substansi berupa penghormatan terhadap "air/ tirta" masih dipertahankan.

- Tradisi yang maih hidup tersebut perlu dilestarikan sebagai aset budaya yang bernilai tinggi dan merupakan salah satu identitas/ jatidiri budaya Jawa/ bangsa kita. 


\section{KEPUSTAKAAN}

Anonim, 1991. Ensiklopedi Indonesia, PT Cipta Adi Pustaka, Jakarta

Casparis, J.G. De, 1956. Prasasti Indonesia II Selected inscription from the $7^{\text {th }}$ the $9^{\text {th }}$ century A.D. (Djawatan Purbakala RI, Djakarta.

Kramer, C., 1979. Etnoarcheology: Implications of Etnography for Archaeology, New York: Coloumbia University Press.

Koentjaraningrat, 1974. Beberapa Pokok Antropologi Sosial. Penerbit PT Dian Rakyat, Jakarta.

Moertjipto, dkk, 1994/1995, Fungsi Upacara Tradisional Bagi Masyarakat Pendukungnya Masa kini, Depdikbud, Proyek Pengkajian dan Pembinaan Nilai-Nilai Budaya Daerah Istimewa Yogyakarta.

Nareswara, 1993. "Pengertian Dan Fungsi Petirtaan Pada Masa Klasik Di Jawa", Sripsi, Fakultas Sastra UGM, Yogyakarta.

Soeroso, 1982, "Fungsi Petirtaan Cabean Kunti Bagi Masyarakat Jawa Kuna", Skripsi, Fakultas Sastra, UGM, Yogyakarta.

Soekmono, 1977. Candi Fungsi dan Pengertiannya IKIP, Semarang Press

Sukarto K. Atmodjo, 1982. Arti Air Penghidupan Dalam Masyarakat Jawa (Yogyakarta: Proyek Javanologi).

Spradley, James. 1979. The Etnographic Interview. New York: Holt Rinehart.

Suparlan, Parsudi "Perubahan Kebudayaan" Buletin Antropologi No 15 tahun II. Penerbit Perpustakaan Sastra UGM.

Woyowasito S, 1977. Kamus Jawa. CV. Pengarang, Bandung.

Lelono, Hari, 2000, Perilaku Masyarakat Jawa Dalam Pemanfaatan Sumber Air (Studi Kasus Kegiatan di Situs Candi Petirtaan). LPA (Laporan Penelitian Arkeologi). Balai Arkeologi Yogyakarta. 